\title{
HVMANITAS
}

Ressurreição dos ossos

Autor(es): $\quad$ Medeiros, Walter de

Publicado por: Faculdade de Letras da Universidade de Coimbra, Instituto de Estudos

URL

persistente: URI:http://hdl.handle.net/10316.2/23173

DOI: $\quad$ DOI:http://dx.doi.org/10.14195/2183-1718_63_32

Accessed : $\quad$ 26-Apr-2023 04:55:24

A navegação consulta e descarregamento dos títulos inseridos nas Bibliotecas Digitais UC Digitalis, UC Pombalina e UC Impactum, pressupõem a aceitação plena e sem reservas dos Termos e Condições de Uso destas Bibliotecas Digitais, disponíveis em https://digitalis.uc.pt/pt-pt/termos.

Conforme exposto nos referidos Termos e Condições de Uso, o descarregamento de títulos de acesso restrito requer uma licença válida de autorização devendo o utilizador aceder ao(s) documento(s) a partir de um endereço de IP da instituição detentora da supramencionada licença.

Ao utilizador é apenas permitido o descarregamento para uso pessoal, pelo que o emprego do(s) título(s) descarregado(s) para outro fim, designadamente comercial, carece de autorização do respetivo autor ou editor da obra.

Na medida em que todas as obras da UC Digitalis se encontram protegidas pelo Código do Direito de Autor e Direitos Conexos e demais legislação aplicável, toda a cópia, parcial ou total, deste documento, nos casos em que é legalmente admitida, deverá conter ou fazer-se acompanhar por este aviso. 
humanitas

Vol. LXIII

2011 


\section{RESSURREIÇÃO DOS OSSOS}

Segunda metade do século XIX. Primeira metade do século XX. Quase não havia sarau ou sessão de gala em que faltasse o recitativo comovido de $O$ Noivado do Sepulcro.

O seu autor, Joaquim Soares de Passos, tinha sólida formação clássica, com o pai, com os irmãos. Entre os autores preferidos, um elegíaco ardente: Propércio. A mulher amada, a noite, a lua, o campanário, a escada, a melancolia, a campa, a insónia, a deslembrança, as árvores ferais, a voz do além - são ingredientes desoladores desta poesia.

Desoladores também para quem a cultivou. Soares de Passos sucumbe, ainda jovem, à tuberculose. Não se lhe conhecem paixões devorantes. Mas podia vivê-las quem falou do entrechoque de esqueletos em estos de amor. Mais longe da morte. Mais perto da esperança.

Walter de Medeiros

A J.R.F.

\section{POALHA DE PUREZA}

No trilho árduo da imortalidade, conquistou ciência, arte e benquerença.

Deus lhe concedeu que triunfasse: e na glória e na amizade ganhou primazia entre os Grandes.

W. M. 